\title{
The Rocky Marriage Between Public Administration Academics and Practitioners
}

\author{
Sunday I. Odezah \\ The University of Oklahoma, Oklahoma, USA
}

\begin{abstract}
It has long been recognized that public administration (PA) is a "prophet without a prophecy", a situation in which PA theories and research cannot predict, tell, explain, or solve the problems facing PA practitioners. Consequently, this problem has resulted in a lack of congruence, gap, disconnect, division, or gulf between PA academics and practitioners. Although volumes have been written about the problem, much of this work is based strictly on the "scientific" research method which has little or no potential relevance to the problems facing PA practitioners. In contrast, this paper uses both the scientific and the "case study" research methods to provide a more balanced view of the problem. To illustrate, after discussing the nature of the causes of the disconnect between PA academics and practitioners from a theoretical point of view, the discussion then applied a case study research method to show how the "theory-practice" and "research-practice” gaps might have contributed, directly or indirectly and in whole or in part, to the failure of the American anti-poverty programs, popularly known as the "American war on poverty". The paper concludes with some results-oriented and productive recommendations to bridge the theory-practice and the research-practice gaps in public administration, the disconnect between PA academics and practitioners, and to move the public administration profession in the right direction.
\end{abstract}

Keywords: public administration, theory-practice gap, research-practice gap, pracademics

Once upon a time (late 1920s through early 1940s), American public administration (PA), as a field of study, was highly respected, admired, and reputed because those who held government jobs as public servants did an excellent job. According to Henry (1995), public administration reached its reputational zenith during the period from 1927 to 1937. He added: "Public administrationists were courted by industry and government alike during the 1930s and early 1940s for their managerial knowledge (and expertise)”. However, with the passage of time, public administration's image, prestige, respect, and reputation (just to name a few) gave way to the saying "good things don't last" and eventually faded and vanished from the radar. The inevitable question is: What went wrong with American public administration after the 1940s and even to this day? Admittedly, there are no easy or simple answers to this question. Nevertheless, this paper strives to provide partial answers to the question. The answers are partial because some of the problems in American public administration will remain a conundrum with no clear-cut answers. A good example is the question: Why in the world is "poverty" still a critical problem in America — the richest and the most powerful and industrialized nation on planet earth—despite the trillions of dollars that American government has spent on the anti-poverty programs or the war on poverty to eradicate

Corresponding author: Sunday I. Odezah, Doctor of Public Administration (DPA), management consultant, the University of Oklahoma; research fields: public management, leadership, administrative theory, nonprofit leadership and management. 
poverty in America? This "soul-searching” question and mystery about poverty in America will be addressed in detail later.

One place to look for the answer to the question "what went wrong with American public administration after the 1940s and even to this day" is the biblical statement that says: "if a house (or kingdom) be divided against itself, that house or kingdom cannot stand” (Mark 3: 25 KJV). To draw the point home, the literature on the American public administration overwhelmingly indicates that there is an internal war that is raging between public administration academics and practitioners - the two sides of public administration that are supposed to work together in tandem and in harmony to implement government or public programs and policies. In simple terms, the war is about the "disconnect” or "divide” between PA academics and practitioners. In other words, when the house or kingdom (public administration, in this case) divided itself, the field became a "Babel Tower", a catastrophic, "things fall apart" situation that made PA academics and practitioners to speak different languages and to go their separate ways. As a result, the two parties, have not, even to this day, been of much assistance (if at all) to each other, especially in the implementation of government programs and policies. With advanced education, one would think that over time the relationship between the two parties would improve, but according to Markides (2007), Hartmann and Raadschelders (2011), and Tsui (2013), this is not the case. Instead, the relationship between the two parties continues to deteriorate. Ironically and as one would expect, this sad situation has produced two undesirable consequences in American public administration.

First, the disconnect between PA academics and practitioners has caused and continues to cause serious catastrophic consequences for the theory, study, and practice of public administration. The situation got so bad in the 1970s that an astute observer, Allen Schick, concluded: "Public administration had come apart and could not be put together again” (Schick, 1975, p. 157). Maybe so, but one of the purposes of this paper is to show that it is never too late to once again put back together public administration and steer the field in the right direction. For one reason, public administration, as a field of study, is too valuable to government to let it die a quiet and premature death. Yes, public administration is plagued with all sorts of problems, but the field has a bright future.

Second, the disconnect between PA academics and practitioners has resulted in what the author may call, for lack of a better word, "public administration cannibalism", a situation in which both PA academics and practitioners maintain their individual egos, personalities, and boundaries and cast lots for blaming each other for the disconnect between them. In this cannibalistic situation, each side claims to be right and to be doing the right thing while blaming the other side for the problem. Unfortunately, in this blame game, the two wrongs have, so far, not made one right.

The following observations cast additional insight into the tension between PA academics and practitioners. As Posner (2009) put it, "While the field of public administration was in no small part premised on sustaining a healthy academic-practitioner connection, there has been a retreat from engagement due to deeply rooted trends in both academic and practitioner environments". He added: "One of the more alarming signs of disengagement is the retreat of practitioners from participation in conferences of such organizations as ASPA (American Society for Public Administration), whose trademark is bringing together academics and practitioners”. Along these lines, Newland (2000) said: “ASPA was founded on the ideal of connectedness among practitioners and academicians, across specializations, and between senior and younger professionals. The first part of that foundation now barely survives”. According to Stivers (2000), one theme that consistently emerged at the 1999 Building Bridges Tour of Public Administration Review (PAR) 
Was the tension between the needs of practitioners and the needs of academics. He added, many practitioners felt that $P A R$ is not meeting their needs or serving their interests because the "the articles are...not relevant to the day to day operations of government management”.

Gibson and Deadrick put it this way:

Scholars and practitioners comprise the "community" of public administration. The founding mothers and fathers of the field, the original "pracademics", formulated a profoundly unique identity of unity between those who study and those who perform public administration. However, there seems to be a perpetual division within the "community", an identity crisis of sorts which threatens the mission of service each carries for the other. There is a proclaimed lack of interest and perceived utility of what each brings to the table, ensuring a growing chasm in which public administration, as a whole, suffers. (Gibson \& Deadrick, 2010, pp. 145-146)

Surprisingly, the disconnect between PA academics and practitioners is an aberration and a new practice that has put asunder between the two parties. Evidence of this assertion abounds. For example, according to Bushouse et al. (2011), "There was a strong connection between the academic and practitioner worlds when PA emerged as a field of study in the early 20th century”. Similarly, Bolton and Stolcis (2003) asserted that:

The disconnect in public administration is a relatively recent phenomenon. Gulick, White, and Merriam, as well as many of the field's other founding fathers, saw little difference between practice and theory, partly because they were both practitioners and scholars, the original pracademics.

Posner (2009) expanded on Bolton's and Stolcis' observation when he said:

Indeed, the founding "fathers" of public administration were often boundary spanners-people who had careers rooted in both academic and public service camps. Luther Gulick, for instance, coupled his well-known theory building and academic service with a distinguished career tackling an array of high-profile public management problems... he served on the Brownlow committee, assembled by President Roosevelt, which made path-breaking changes to the organization of the federal government, followed by important roles in managing New York City’s government. He served for three years as the City Administrator under Mayor Robert Wagner. Similarly, Wallace Sayre, a leading public administration scholar at Columbia University, served as Chairman of the New York City Civil Service Commission under Wagner...

Although the focus of this paper is on public administration, it is instructive to note that the disconnect between academics and practitioners is not restricted to public administration; it is also found in other professions as well. To illustrate, Bennis and O’Toole (2005) asserted that business schools are on the wrong track and have lost their way because they have adopted the scientific model of physicists and economists which has little or no potential relevance to the problems facing business managers. Along this line, Khurana and Marquis (2006) pointed out that "During the past several years, a number of scholars have noted that business school research has had little impact on management”. As far back as the 1970s, Mintzberg (1973) had this to say:

...we must recognize that although the management school gives students M.B.A. and M.P.A. degrees, it does not in fact teach them how to management. Hence these degrees can hardly be considered prerequisites for managing, and the world is full of highly competent managers who have never spent one day in a management course.

Thirty one years later, Mintzberg (2004) asserted that what is taught in MBA programs is at odds with what managers need to know to do their job efficiently and effectively.

From the field of social work, Thomas (1994) questioned the utility of scholarly research to practitioners in the field and concluded that there is a "trench between the worlds of theory and practice wisdom". From the 
organizational science front, Susman and Evered (1978) noted that there is a crisis in the field and the principal symptom of the crisis is that as our research methods and techniques have become more sophisticated, they have also become increasingly less useful for solving the practical problems that members of organizations face. More examples in other fields can be cited but doing so just to fill the available space will not serve any useful purpose in this paper. That said, the remainder of the paper proceeds as follows.

The first section discusses what the author feels are the most critical causes of the disconnect between PA academics and practitioners. The second section uses, as a case study, the "American war on poverty" to illustrate the negative effects or drawbacks of the disconnect between PA academics and practitioners in the practical implementation of public administration. The third section summarizes the information in the previous sections and draws the paper to a conclusion. The fourth and final section offers some recommendations to: (1) bridge the gaps between theory and practice and between research and practice; (2) remove the disconnect between PA academics and practitioners; and (3) move the public administration profession in the right direction.

\section{Causes of the Disconnect or Divide Between PA Academics and Practitioners}

As indicated earlier, a war is raging between PA academics and practitioners, so much so that the war has torn the two parties apart. What follows is a discussion of three factors that the author believes are the causes of the war between PA academics and practitioners. The three factors are the "theory-practice" gap, the "research-practice" gap, and the "faulty faculty reward system".

\section{The Theory-Practice Gap}

To set the stage, it is essential to distinguish between "theory" and "practice". Variously defined and as used in this paper, theory is one's understanding of the world while practice is the enactment of that understanding (Englehart, 2001). Viewed from this perspective, practice tells us what is happening in the real world and theory helps us to understand why it is happening. As Stallings (1986) put it, “...theories are merely clusters of statements that explain something. Before there is a need for theories...it is first necessary to establish what needs to be explained. What are the core problems in the field to which theories can be applied”? Let the author do a reality check here. The ordering of the words and ideas in Stallings' definition of theory is important. Simply put, "problem identification" is a prerequisite to "crafting a theory", not the other way around. In other words, the problem or what is happening takes precedence over theory-the explanation of what is happening. Having distinguished between theory and practice, what follows is a brief discussion of the problem with public administration theories and their ramifications on the practice of public administration.

From the inception of public administration as a field of study in the United States, the profession has been plagued with all sorts of problems, principal among which are the profession's theories. The following observations will make this point clear. Over 30 years ago, David H. Rosenbloom (1983) sent shockwaves to the public administration community when he said: "It has been recognized for some time that the discipline of public administration is plagued by a weak or absent theoretical core”. Guess what, this statement echoed and spread like wild fire within the public administration community and it was quickly picked up by other scholars in the field. For example, according to Kettl (2000), "In the middle of the twentieth century, public administration found itself under attack by both academics and practitioners for theory that provided only weak guidance" (italic in the original). More recently, Ferd and Cheryl Mitchell (2015) noted that "(public 
administration) is sometimes criticized as not based on a 'comprehensive theory' of administration and lacking a core knowledge base”.

One explanation for the observations raised by Rosenbloom, Kettl, and the Mitchells is that "public administration prophets" (Pollitt, 2010) or theorists got into trouble with theories because they were regarded as prophets without a prophecy. In other words, public administration got into trouble because its theories (prophecies) pointed in one direction while its practices went in another direction. Question! Why are public administration theories not in accord with the realities of public administration or why is there a gap between public administration theories and practice? There are several places to look for the answer to these questions, including the following.

First and foremost, no matter how hard theorists try to figure out everything under the sun, there is a limit to how far they can go. For one reason, theorists try to do something about something they can do nothing about. The truth is, in life there will always be some unanswered questions that only God can answer, not a theorist in an academic laboratory. Trying to answer such questions with a theory is like putting a question mark where God has already put a period. As smart as theorists may be, they will always get into trouble if they challenge God's intelligence.

Second, most theories, if not all, are self-fulfilling prophecies in the sense that they are expressions of what their authors think and feel about the world in which they live. Here lies the problem. What if their understanding of the world or problem is wrong as is usually the case? Under this condition, the theory will be misleading and worse than the problem it is intended to solve. Furthermore, because theorists do not perfectly understand the world in which they live, it is not uncommon for them to craft a theory based on the slogan, "You've got to fake it until you get it right". No wonder Mintzberg said: "so-called theories of management rest upon a false picture of what managers actually do" (Stallings, 1986). In concurrence with Mintzberg, the question is: How can a theorist who has never been a manager or even visited an organization such as Walmart know what managers actually do or the problems facing them? Only a faker or a false theorist can do that.

The point is that, no matter how smart or brilliant theorists are, it is difficult, if not impossible, for them to craft an exact theory of management because management is multifaceted and too broad to be carried out with precise formulas. Behn (1995) put it very well when he said: "the big questions of public management will not be answered with a shout of 'Eureka' —one sudden insight... The big questions of public management do not have a single answer-or even a single answer plus or minus 10 percent”.

A major consequence of theories is that the world is in trouble today because people make judgments about other people based on untested and unproven theories rather than from observing what is actually happening in the real world. “Theory X” by McGregor (1960) which, in simple terms, assumes that people are inherently lazy; they dislike work and try to avoid it as much as they can is a typical example. Guess what, after a critical reality check, the theory died a quiet death.

Third, according to Englehart (2001), the scientific model of theory puts administrators off because this type of theory seems to hold itself above the field of practice.

Fourth, as Nicki King noted,

There are built-in tensions which in providing rigor, pull theorists too far into the world of abstraction and unreality. Their theories about guidance are impressive intellectual statements that (often) bear no relation to the operation of social systems in a modern world. (Ventriss, 1991) 
Notwithstanding the above-mentioned drawbacks of theories, they are still defended by their proponents on several grounds. To illustrate, as James pointed out, "People who use theory work smart because it takes 'far less mental effort' to understand the complexity of the world. Theory is a 'labor saving contrivance'-a tool that helps us make sense of the world” (Shields, 2006). While the author applauds James for his insights, he cautions that working smart is not the same as working intelligently. As a matter of fact, a smart worker can also be a crook; and crooks are unreliable and untrustworthy. Second and as stated earlier, since theories are personal feelings and self-fulfilling prophecies, they cannot be regarded as tools that help people make sense of the world. Only empirically and scientifically proven research and observation can do that, not abstract theories.

Recognizing that the academic and practical worlds are different and that there are a bunch of theories out there, the question then becomes: How would a public manager or any manager for that matter looking for an answer to the problem facing him or her know which theory to use? In answer, the advice Moses gave to the Israelites is instructive. To illustrate, when the Israelites asked him (Moses, their leader) the question: "How shall we know whether the prophecy is from the Lord or not”? Moses unequivocally said: "If the thing (the prophet) prophesies doesn't happen, it is not the Lord who has given him the message; he has made it up himself” (Deut. 18: 22, TLB).

Based on Moses' answer, here is how to distinguish between a real and unreal theory. If a theory fails to explain what it purports to explain and/or solve the problem facing practitioners, it is not a real or true theory and it should be removed from the academic literature or vocabulary before it misleads and causes practitioners to make wrong and costly decisions. On the other hand, if the theory provides a valid explanation or answer to a particular problem, the theory is a real one and it should be kept in the academic literature or vocabulary for practitioners to use. The point is that, from a practical perspective, a theory must be relevant, problem-oriented and be able to explain what is happening. Hence, the author agrees with Kurt Lewin's observation that "there is nothing so practical as a good theory" (Perry, 1993). Behn (1993) put it this way, "the test of a good theory is whether it actually helps managers in their efforts to improve the performance of their organizations”. That said, the author's advice to PA practitioners is that they should strive to identify and utilize only empirically proven theories that are in accord with the realities of life. As one CEO put it, "Good managers make good decisions because they operate by proven methods” (Meyer, 2001). This statement makes a lot of sense, especially in today's rapidly changing and unpredictable world in which managers work and in which yesterday's theories may not solve today's problems. As the saying goes, “You can’t do today’s job with yesterday's methods and be in business tomorrow".

\section{The Research-Practice Gap}

As a point of departure, it should be noted upfront that the issues addressed in this section are based on the popular belief that "academics are knowledge producers" while "practitioners are knowledge users". In this "output-input" type of relationship, the glue that holds the two parties together is "knowledge utilization". Invariably, this means that practitioners are interested in usable knowledge while academics are concerned with producing and advancing knowledge. It also means that if the knowledge produced by academics is not used by practitioners, it is good for nothing, but to be cast out into the waste basket, dust-bin, or disposal. Although the author may unintentionally over exaggerate the problem, the literature overwhelmingly points to the fact that most, if not all, academic research in almost every field of study do not address the needs of practitioners. The following quote is a case in point. 
Researchers use theories without carefully analyzing the accuracy of the theory's basic premises and its relevance to the problem being studied. These criticisms have converged on a common concern-that research has changed its focus and primary goal from producing knowledge to publishing papers, from improving practice to advancing the researcher's own career. The end result is that our research may be not only irrelevant to practice but also irrelevant to knowledge. (Tsui, 2013)

Examples of how academic research is out of phase with the needs of practitioners follow.

Topping the list in this paper is the observation made by Watson and Montjoy (1991). As they put it, "our concern is that the public administration literature (and, presumably research) is not focusing on the really important issues facing public administrators”. Bushouse et al. (2011) posed a similar question: How can PA be relevant if the knowledge it is producing is not being applied? They added: "PA research is conducted outside of practice and research questions are driven by academic discourse rather than the pressing problems of public managers, resulting in a gap between what researchers research and what practitioners need”. Similarly, Beyer and Trice (1982) asserted: "the most persistent observation in the literature on utilization is that researchers and users belong to separate communities with very different values and ideologies and that these differences impede utilization”. According to Bolton and Stolcis (2003), “Academics are trained to generate knowledge in their respective disciplines, not necessarily to solve organizational problems. This tendency does not lend itself to conducting research that concerns itself with practical problems". Last but certainly not least, Posner (2009) stated, "Research undertaken by academics is focused on publication in academic journals, not on the potential relevance to the problems facing...managers".

To draw the point home, it is instructive to narrate the story and experience of a "former New York Police Department commissioner and current Los Angeles Police Department chief, William Bratton”. This chilling story illustrates the mismatch and gap between PA theory/research and practice in a practical way and how PA theories and research have increasingly become useless to PA practitioners. It also serves as a wake-up call for the PA community—both academics and practitioners—-to take a more aggressive and urgent remedial action about the gap between PA theories/research and practice before it causes further damages to the PA profession. That said, here is the story: According to Bolton and Stolcis (2003),

William Bratton lamented academic research as essentially irrelevant to law enforcement administration... By the end of his remarks, Bratton had carefully outlined how the success he had achieved as NYPD commissioner resulted from his use of practical management skills that all but ignored social science.

Although Bratton probably overstated the problem, it nevertheless, sounds realistic because according to Henry Mintzberg, an internationally renowned academician and author on management, "managing is an art, not a science" (Mintzberg, 1973, p. 174). To this might be added the following: The beginning of administrative wisdom is the awareness that there is no one optimum or "one best way" type of management system, style, or paradigm (e.g., Burns \& Stalker, 1994). To illustrate these points, there are other PA practitioners before Bratton who used their intuition, common sense, and wisdom rather than academic theory and research to make the best, intelligent decisions the world has ever known. A classic example is King Solomon, the third king of Israel, whose decision between two prostitutes who lay claim to a newborn child resulted in saving the life of the child and in rewarding the real mother with the child (1 Kings 3: 16-28, KJV). Another way to visualize the reality in Bratton's case is that when it really comes down to the issue of management, management is, for the most part, a matter of common sense and wisdom, not necessarily academic theories and research. To substantiate this assertion, the author is yet to see a manager in the United 
States and even in primitive societies who replaced his or her brain with academic theory or research, or "they told me” mentalities and made wise decisions that benefited all parties concerned.

Bratton's and King Solomon's experiences indicate that PA theories and research are only as good as they sound in the academic world but outside that world, they have no place in the practical world that deals with the realities of life. The following incisive quote attests to this claim.

The role of theory is defined as developing the basic concepts of a field, while the role of practice is to apply it. But, this does not fit well with the realities of public administration ... (PA) practitioners often find it difficult to relate the efforts of theory-developers to the complex realities of everyday work. (F. H. Mitchell \& C. C. Mitchell, 2015)

Notwithstanding their shortcomings, PA theories and research have their defenders and advocates. For example, several PA theorists and researchers have fought back to defend PA theories and research. To illustrate, Meier feels that "many of the concerns of (PA) practitioners are just not very interesting" (Shields, 2006). Like Meier, Stallings (1986) defended PA researchers for not doing problem-driven research that is tailored to the needs of PA practitioners. As he put it,

There is a more general reason why the problems of practitioners should not automatically be taken as the core problems of the field. The substance or content of a particular practical problem does not make it theoretically important. Such daily concerns as how to control a recalcitrant subordinate, how to diffuse angry citizens, how to deal with a mayor who is more interested in his/her political future than in a particular city department, etc., are not by themselves theoretically valuable research topics. (Stallings, 1986, p. 237)

Given that in a democratic society people have the right to their opinion, Meier and Stallings are right in their opinions. Nevertheless, the author has some reservations about their opinions.

First, with regard to Meier's argument that "many of the concerns of (PA) practitioners are just not very interesting”, it is instructive to mention that according to the ASPA Code of Ethics, both PA academics and practitioners are in the business of advancing, promoting, and/or serving the public interest. These interests which ultimately are the concerns of (PA) practitioners are the reason for the existence of government and ASPA.

Second, it is also instructive to mention that what government does is not always interesting. Put another way around, government does not always do the right thing. To paraphrase Moe (1994), the management of government is not like the management of General Electric or the Ritz-Carlton Hotels. Government does not have the option available to private sector companies of simply stopping the performance of some activities because it is not profitable or interesting. This means that even if the activity (e.g., the notorious American food stamp program) does not make any sense, government will still continue with it for several reasons, including politics. The fact of the matter is that, for better or worse, the "public interest" that government and ASPA are called upon to serve can be both interesting and uninteresting. To illustrate, a cold-blooded war-killing another human being, including American soldiers-is not interesting and fun. Second, killing another human being is directly against the 6th commandment of God which says "Thou shalt not kill” (Exodus 20: $13 \mathrm{KJV}$ ). However, in the name of security, American presidents, as Commander in Chief of the armed forces of the United States, have (explicitly or implicitly) a constitutional mandate, obligation, and responsibility to defend American people by going into war with other nations. Hence, former U.S. President, George W. Bush, is always proud to say "America is safer today without Saddam Hussein”, former and late president of Iraq. Although many people in the United States and around the world did not support the war in Iraq, President Bush felt he did the 
right thing because as indicated above, he did exactly what the Constitution of the United States required him to do - to ensure that the laws, wise and unwise, of the United States, including the provision for the common defense as stated in the preamble to the U.S. Constitution, are faithfully executed.

Furthermore, as the author has written elsewhere (Odezah, 2016), “...American welfare system stinks because it encourages unmarried teenage girls to stay home and make more babies in order to receive more welfare benefits". In addition, the system encourages dependency on government rather than self-sufficiency and self-support because it weakens work incentives and perpetuates dependence on Uncle Sam. As ugly, disgusting, and disgraceful as these sentences sound, they do not prevent American government from caring for poor Americans. One reason is that American government is built on certain moral, spiritual, godly, and humanistic principles that will make it difficult, if not impossible, to not care for the welfare of its people because their problems and concerns are not interesting. The following statements will make this point clear.

First and foremost, as far as the author can tell, the United States is the only nation under the sun that prefaces its constitution - the law of the land —with the words "We the people" and "promote the general welfare". By implication, this behooves American government to take care of its people, even if their problems and concerns are not interesting. By the way, in a democratic society such as America, who decides whether a public interest, issue, or problem is interesting or not? Unless, the author misunderstood the United States Constitution (if so, the author's apology), such decisions are made by the elected officials, not unelected and politically unrecognized PA theorists and/or academicians.

Second, as Tocqueville noted after the Grand Convention of 1787, "The people reign in the American political world as the Deity does in the Universe. They are the cause and the aim of all things; everything comes from them and everything is absorbed by them" (Stillman, 1987). If the author understands Tocqueville's observation correctly, it does not say that American government should neglect, trash, or get rid of its people because their problems and concerns are not interesting. Conversely, the opposite is true because the people, not public administration theories and research, reign in the American political world.

Third, in the campaign for the adoption of the U.S. Constitution, one of the founding fathers, James Madison, asserted: If men were angels, no government would be necessary (Wills, 1982). To this might be added, if American government were only concerned about interesting issues, there would be no need for government in America because as the saying goes, “If it's not broke, don't fix it”. Unfortunately, however, in an imperfect, immoral, and sinful world in which men and women are not angels, something is always broke and government is always fixing something; hence government is necessary and is here to stay. This means that regardless of whether American people are angels, imperfect, sinners, criminals, etc., American government has, as stipulated in its constitution, the moral responsibility and obligation to take care of its people, irrespective of whether or not their problems and concerns are interesting or not.

Fourth, as far as the author can tell, America is regarded as a nation under God. For a nation under God to ignore or neglect its own people because their problems and concerns are not interesting is morally and spiritually wrong. Besides, such actions can open the gate to hell.

Fifth, during the 1787 American Constitutional Convention, one of the founding fathers, Benjamin Franklin, asserted: "I agree to this Constitution with all its faults” (MacArthur, 1996). What Franklin meant was that even though the U.S. Constitution is not perfect because it was not written by perfect human beings like angels, it is still the law of the land that shapes and directs the lives of American people. Hence, the constitution is here to stay. Also, despite the fact that the U.S. Constitution is imperfect, it has stood the test of time, 
provided direction for American government, and become the envy of the world. Consistent with Franklin's comment about the U.S. Constitution, Cardinal John Henry Newman once said: "nothing would ever be done if we waited until we could do it so perfectly that no one could find fault with it” (Pierce, 2001).

The above two quotations indicate that contrary to Meier's belief that many of the concerns of (PA) practitioners are not interesting and Stallings' belief that the problems of practitioners should not be taken as the core problems of the field, government is not designed to serve only angels without blemishes. Rather, government in the United States and around the world is designed to serve people from all walks of life, including winos and prostitutes; and there is absolutely nothing the PA theorists and researchers can do about it. That said, American public administration theorists and researchers (PA prophets and evangelists) are well advised to do exactly what the United States Constitution, Tocqueville, Madison, Franklin, and Newman did or stood for-serving the interests of all Americans, not just those whose problems and concerns are interesting. To serve only the interests of the latter group of people is not only immoral, unethical, and inhuman; it also opens the gate to hell and nobody, even criminals, wants to go to hell.

And now, let the author do a critical reality check on Stallings' arguments. In a nutshell, Stallings said: The problems of practitioners should not automatically be taken as the core problems of the field of public administration or management. He also said: Such daily concerns as how to... deal with a mayor who is more interested in his or her political future than in a particular city department, etc., are not by themselves theoretically valuable research topics.

Quite frankly, the first part of Stallings' arguments is provocative because it raises a cascade of questions that lie at the core of public administration. For example, if the problems of PA practitioners should not be taken as the core problems of the field, why are the PA practitioners working in the field and what exactly are they doing; what is the purpose of public administration, etc.? The answers to these questions are reserved for another day in another paper. Nevertheless, it suffices here to say that Stallings' provocative argument that the problems of PA practitioners should not be taken as the core problems of the field is unwarranted because public administration exists to serve the public interest and that is exactly what the PA practitioners are doing in the field.

Stallings' second argument that "dealing with a mayor who is more interested in his or her political future than in a particular city department is not by itself a theoretically valuable research topic" raises more questions than it answers. The real problem is that today it is possible to find tenured full professors of public administration or management who have never set foot inside a city hall or seen a mayor, let alone knowing the problem(s) he/she is facing. This may be the major reason why most, if not all, PA academic research is not problem-driven or tailored to meet the needs of PA practitioners (e.g., mayors) because their authors-the PA researchers - do not know that such needs or problems exist. Even if they do, their research will not provide any useful solution to the problems because as Rosenbloom, Kettl, and the Mitchells have stated, public administration theories only provide weak guidance.

To recap, according to Waldo (1968), "PA is an applied field that should focus on solving the key challenges, whether interesting or not (emphasis added), facing the public sector". Unlike business that has a profit bottom line and motive, government does not have a profit bottom line, motive, and option to stop providing certain services to the people because they are not profitable or interesting. In this regard, American PA practitioners, like the former President Bush's case discussed earlier, are only upholding the public interest (not their private interests), irrespective of whether those interests are interesting or not. The public service is a 
noble calling and the PA practitioners who sacrificially and willingly responded to that calling deserve respect and praise (not censorship), especially from their fellow public administration colleagues—-the PA academics.

\section{The Faulty Faculty Reward System}

Today, more than ever before, the logo and password in academic institutions are summarized in three words_-"publish or perish”. Guess what, faculty members get the message. In response, their logo and password are not three words but one powerful word-“survival”. Sadly enough, the publish or perish policy in academia has created a "moral hazard" problem—what is rewarded—in academic institutions. Arguably, the policy has also created an environment in which PA academics can say to the PA practitioners: To hell with you; who gives a damn about your needs and problems? In turn, these two problems have further widened the gap between theory and practice and the divide between academics and practitioners. To illustrate, in order to survive, faculty members have discovered various ways to beat the system by publishing anything under the sun as long as the publication enhances the image, prestige, and reputation of their academic institutions but not what practitioners need to do their job effectively. After all, faculty members are not stupid. If academic institutions tell them that they will not be promoted and tenured for not publishing, any decent, smart, rational, and good faculty member who wants progress and who wants to keep his/her job will do whatever it takes to beat the system by publishing anything that crosses his/her mind. This attitude which has increasingly become the only way to survive in academia has led one renowned CEO to conclude that "academic publishing is a 'vast wasteland' from the point of view of business practitioners” (Bennis \& O’Toole, 2005). Tsui (2013) put it this way, "The research enterprise or university becomes a paper generation factory with young scholars worrying about surviving publication pressures and meeting promotion and tenure requirements, and many face repeated rejections from journals". To these might also be added: Most academic publishing is a "wishful thinking" and "a prophet without a prophecy" whose prophecies will never come to pass or be realized. Of course, faculty members know this but as stated earlier, the name of the game is survival, not intelligence because faculty members do not eat intelligence; they eat food.

Having said all that, what follows is a brief discussion of the nature of the academic reward systems that are purposely designed by academic institutions to discourage faculty members from doing research that is problem-driven or research that is relevant and useful to the practitioners' needs. Again, although the major focus of this paper is on public administration, the faulty reward system has increasingly become an "academic flu”, so much so that the flu virus has virtually affected all academic institutions and professions. Hence, in order to have a balanced view of the problem, the discussion that follows includes public administration and other professions.

Starting with the public administration profession, Bushouse et al. (2011) in their article entitled "Crossing the Divide: Building Bridges between Public Administration Practitioners and Scholars” asserted that:

Programs enhance reputations, and hence rankings, by having faculty published in prominent academic outlets. As a result, programs are encouraged to reward faculty more for publications in top journals relevant to the interests of a select academic community rather than for their contributions to solving real world problems or their efforts at addressing issues that provide value to the larger (public administration) community.

From the business administration front, Bennis and O’Toole (2005) said:

...a management professor who publishes rigorously executed studies in the highly quantitative Administrative 
Science Quarterly is considered a star, while an academic whose articles appear in the accessible pages of a professional review — which is much more likely to influence business practice_-risks being denied tenure. We know of no scholar at a first-rate business school with a good publishing record who has been denied tenure or promotion for being a poor teacher or for being unable to teach effectively in executive education programs, where teachers must have real-world experience. But we do know of a professor of finance who was denied promotion when his department decided he was not a serious scholar. The damning evidence against him included seven articles in this publication (not specified) and the highest teaching ratings in his department.

Even more troubling, Bennis and O’Toole noted that "One traditional factor in tenure decisions is how often a candidate's work is cited by other scholars”. Alas, given the discriminatory and evil nature of human beings, this factor raises more questions than it answers. To illustrate, citing an author's work by other scholars is, among others, a function of who the author is because scholars are basically free to cite who they want to cite irrespective of the quality of the author's work. For example, scholar John does not have to cite scholar Joe's work if John does not know or like Joe. Even worse, John can still use Joe's ideas in a twisted and crooked way without giving him credit for his brilliant ideas. Furthermore, if the author's picture appears in the article with his/her nationality, ethnic background, and sex shown as black, white, etc., and as male or female, this alone can easily turn off a racist and an evil, wicked scholar from citing the article and the author's name. In this case, women and minorities, especially foreigners, are likely to be easy targets and victims of discrimination in the tenure and promotion processes in academia. In this scenario, academic institutions are, by and large, only rewarding discrimination (who you know) as opposed to intelligence (what you know). This point may sound ridiculous but it is real in academia today. Second, although it is time-consuming and expensive to do a rigorous and empirical research on this point, such research is, nevertheless, doable- the author's next frontier.

From the information given, tenure and promotion decisions are not only biased against faculty members who write articles to solve problems facing PA practitioners, they are also biased against innocent women and minorities for no fault of their own except for the fact that they are women and minorities. Unfortunately, this immoral and unethical reward system in academia is not likely to go away any time soon unless there is a "spiritual revival" in academic institutions; and only God knows when this will happen.

So far, this paper has discussed extensively the nature and ramifications of the theory-practice and research-practice gaps and the divide or disconnect between PA academics and practitioners from a theoretical perspective. The next section discusses the effects and impacts of these issues on the practical implementation of public administration. More specifically, the discussion uses, as a case study, how the theory-practice and research-practice gaps and the disconnect between PA academics and practitioners may have negatively affected, directly or indirectly and in whole or in part, the performance and effectiveness of the American anti-poverty programs or the war on poverty.

\section{The American War on Poverty}

In order for the audience of this paper to fully understand and comprehend the argument presented herein, the author would like to start the discussion with a metaphor involving the army and airforce on the battle field. To illustrate, in most (if not all) cases, in order for the army to win a war on the ground, it needs "covering fire" or "air strikes" from the airforce by bombing the enemy. Without this help from the airforce, it is difficult for the army to advance safely toward the enemy and to win the ground war. Second, without covering fire from the airforce, there will be a lot of deadly casualties inflicted on the army. So, in effect, covering fire or air 
strikes from the airforce serves at least two purposes - to win a war on the ground and to lessen or avoid casualties on the army. To substantiate this argument, the author saw on his TV screen the other day the following statement: "Fighters jets and bombers central to fight against ISIS falling apart". That said, a discussion of how the theory-practice and research-practice gaps and the disconnect between the PA academics and practitioners may have negatively affected, directly or indirectly or in whole or in part, the operation, performance, effectiveness, and impact of the American war on poverty follows.

As the author has written elsewhere (Odezah, 2016), poverty remains an unsolved global problem, even to this day. With this recognition, the United States has made several efforts to solve the poverty problem in America. For example, in his January 8, 1964 State of the Union address, former President Lyndon B. Johnson proclaimed: "This administration today, here and now, declares unconditional war on poverty in America" (Johnson, 1964a). He added: "Our aim is not only to relieve the symptom of poverty, but to cure it and, above all, to prevent it”. Furthermore, in his March 1964 Special Message to Congress, Johnson declared that his war would strike "at the causes, not just the consequences of poverty" (Johnson, 1964b). As Rector (2014) put it,

When Johnson launched the war on poverty, he wanted to give the poor a "hand up, not a hand out". He stated that his war would shrink welfare rolls and turn the poor from "tax-eaters" into "taxpayers". Johnson's aim was to make poor families self-sufficient, able to rise above poverty through their own earnings without dependence on welfare.

Rector also noted that since President Lyndon Johnson declared unconditional war on poverty in America, the taxpayers have spent $\$ 22$ trillion on the war. He added that an annual poverty report released by the U.S. Census Bureau claimed that in 2013, 14.5 percent of Americans were poor. Remarkably, Rector exclaimed, “that's almost the same poverty rate as in 1967, three years after the War on Poverty started". In terms of cash outlays, President Obama's administration has spent an alarming amount of money to fight the war on poverty in America. According to Tanner (2012), since President Obama took office, federal welfare spending has increased by 41 percent, more than $\$ 193$ billion per year. Twenty three years ago, former Vice President Al Gore (1993) lamented when he said: “We spend \$25 billion a year on welfare, \$27 billion on food stamps, and $\$ 13$ billion on public housing - yet more Americans fall into poverty every year. It is almost as if federal programs were designed (italic in the original) not to work".

Ironically, however, despite all the efforts to "wipe out" poverty in America and despite the fact that American government has spent trillions of dollars to solve the poverty problem in America, the war on poverty is often branded a failure and a catastrophe because "more than 46 million Americans continue to live in poverty” (Tanner, 2012). This paradox and mystery led former President Ronald Reagan to say: “America fought a war on poverty and poverty won” (Edelman, 2012). The question is, what accounts for this sad and undesirable situation and how can it be explained? Truly, there are no easy answers to this question but it deserves attention.

One explanation for the question posed above is the theory-practice and research-practice gaps and the divide or disconnect between PA academics and practitioners problems discussed earlier. The author believes that this explanation makes sense because he does not think that government is filled with a bunch of incompetent people - the PA practitioners who implement the anti-poverty programs - who do not know what they are doing. Rather, he believes that the self-proclaimed PA prophets and evangelists (theorists/researchers) failed or were unable to prophesize the solutions to the war on poverty or to provide covering fire for the PA practitioners by providing them with relevant and useable theory and research information to fight and win the 
war on poverty. Without help from the PA academics, there is little or nothing the PA practitioners can do all by themselves to win the war on poverty because the war is too complicated to be fought by one person or one group of people. A detailed explanation of how the PA academics disappointed the PA practitioners, the entire public administration community, and the American people, or how the PA academics contributed, one way or another, to the failure of the war on poverty follows.

As a point of departure, it is essential to reiterate Kettl's, Rosenbloom's, and the Mitchells' insightful arguments discussed earlier. As Kettl (2000) noted, "In the middle of the twentieth century, public administration found itself under attack by both academics and practitioners for theory that provided only weak guidance". Similarly, Rosenbloom (1983) said: "It has been recognized for some time that the discipline of public administration is plagued by a weak or absent theoretical core". The common denominator or key word in Kettl's and Rosenbloom's arguments is "weak", meaning that PA theories only provide weak guidance, if at all, to the PA practitioners. According to the Mitchells, "the role of theory is defined as developing the basic concepts of a field, while the role of practice is to apply it. But, this does not fit well with the realities of public administration” (F. H. Mitchell \& C. C. Mitchell, 2015). Put together, these three observations imply that most, if not all, PA theories and research are of little or no use to PA practitioners. Under this condition, the beleaguered PA practitioner looking for a theory or research to solve the problem facing him/her is helplessly lost. When this happens, the PA practitioner has no other choice than to look elsewhere for guidance, notably his or her intuition, experience, common sense, and wisdom.

Unfortunately, however, in the case of the American war on poverty, these administrative and implementation weapons are not by themselves sufficient to win the war because as stated earlier, the war on poverty is too complicated to be won with a snap of a finger. Hence, to imitate former President Reagan, America lost the war on poverty because the PA prophets and evangelists (PA theorists and researchers) were nowhere to be found when they were most needed. Presumably, they were in their comfort zones (offices and libraries) theorizing and conducting research to enhance their self-image and prestige and those of their academic institutions, but not to provide information that would aid the PA practitioners to fight and win the war on poverty. Until the PA academics play their part in the governance process, especially in contributing to the implementation of government programs by providing the PA practitioners with useable and results-oriented theories and research, the war on poverty will continue to be a disaster, a catastrophe, a fiasco, and a failure in America.

\section{Conclusions}

As this paper has demonstrated, evidence abounds that there is a great divide between PA academics and practitioners and that the theory-practice and research-practice gaps in public administration, along with the faulty faculty reward system, are what have caused the division. That said, the following advices serve as a wake-up call to the entire public administration community.

First, if public administration must be a profession, a discipline, a science, an art, or by any other name, it cannot continue to operate on theories and research that point in one direction while its practices point in another direction. Thus, in order to steer the public administration profession in the right direction, its theories and research must be in accord with the realities of public administration and solve the problems facing PA practitioners. If not, public administration will continue to be a prophet without a prophecy and a field of study without a focus and purpose. 
Second, although the author does not quibble with the concept and rationale for rewards as a source of incentive and motivation, he has serious reservations about the faculty reward system which discourages faculty members from writing problem-driven articles or articles that address the problems facing PA practitioners. Conversely, the system encourages faculty members to write articles that only enhance the image, prestige, and reputation of academic institutions without regard to whether the articles are useful to PA practitioners. In order for public administration to better and more effectively serve the public administration community, this practice must stop.

Third, the author believes that it is time for public administration to find its niche and stop "muddling through”. For example, he believes that PA academics should spend more time thinking creatively about how to better serve the government and the general public than being bugged down crafting theories and doing research that are of little or no use to the PA practitioners. After all, public administration, according to Woodrow Wilson (1887, 1st ed.), a renowned founder of the American public administration, and Frank Goodnow (1900), the first disciple of Woodrow Wilson, is called into the ministry of implementing government or public programs and policies. As Wilson himself put it, "Public administration is detailed and systematic execution of public law...The broad plans of governmental action are not administrative; the detailed execution of such plans is administrative" (Wilson, 1941, p. 496). According to Goodnow, "the bureaucracy was to administer, in an impartial and nonpolitical fashion, the programs created by the legislative branch, subject only to judicial interpretation” (Milakovich \& Gordon, 2004). Cook (1995) amplified Wilson’s and Goodnow’s ideas when he said: "public administration is the practice of government, the matching of 'special means' to 'general plans'”. Last but certainly not least, Hartmann and Raadschelders (2011) put it this way:

The American study of public administration owes its existence to considerable degree to practitioners (especially those at local and state levels) who-in the context of the rapid changes in the late 19th century-desired to establish academic programs that could combine a generalist's perspective and specialist's skills for those who aspire a public sector career.

Viewed from these perspectives, every other activity in public administration, including the act of crafting theories and doing research is secondary while implementing government or public programs and policies is primary in the hierarchy of the American public administration needs and activities.

Based on the issues raised above, here is the author's advice for the PA academics. Dear PA prophets and evangelists (PA theorists and researchers), please stop the theorizing and get serious with how to make government programs work. As previously stated, you are called into the ministry of implementing government programs and policies as your primary call of duty; every other thing is secondary. Granted, as theorists and researchers, you may not be directly and physically involved in the practical implementation of government programs and policies, but you can be involved in the process by producing relevant and results-oriented theories and research that address the problems facing PA practitioners. That said, the author feels that it is time for PA academics to join hands with PA practitioners and figure out the best way to fight and win the American war on poverty and give poor Americans hope and visions of a better world. This is much better than sitting on the side-line as cheerleaders and observers and watching PA practitioners implement public programs all by themselves.

Furthermore, the author believes that PA academics can do a much better job if they devote more time to how to "make government work better and cost less" and how to make government programs and policies 
achieve their objectives instead of looking for theories and research in all the wrong places or crafting theories and doing research that are not useful to PA practitioners. Hence, the author strongly concurs with the following observations.

First, according to Streib, Slotkin, and Rivera (2001), "Melding the best that academia can offer with the knowledge needs of practicing managers is the way to build a knowledge base that fulfills the traditional promise of the public administration field".

Second, as Porter and Mckibbin have noted, "the problems being researched must also be relevant to the research audience, for all the readable delivery in the world will not make relevant research questions that are deemed fundamentally off-mark or trivial” (Wilkerson, 1999).

Third, Lawler III, Mohrman Jr., Mohrman, Ledford Jr., and Cummings (1999) pointedly argued that for a research project to be useful, it must meet two basic standards: (1) The project must help practitioners understand organizations in a way that will improve practice; and (2) The project must contribute to a theoretically and scientifically useful body of knowledge about organizations.

Fourth, Bolton and Stolcis (2003) asserted that scholarly research must have relevancy and buy-in from practitioners. They added: (Researchers) must better understand that practitioners are charged with solving the most complex and daunting problems facing government organizations. As such, they need research that reflects these challenges and whose findings offer new ways of framing and attacking these issues.

Fifth, Bushouse et al. (2011) said: "crossing the divide between academics and practitioners is critical in order for the academic field of PA to become more relevant to the practice of PA".

In light of the observations discussed above and the issues and problems addressed in this paper, the author joins the aforementioned observers and offers some recommendations (discussed below) to bridge the gaps between theory and practice and between research and practice and, more importantly, to cross or bridge the divide between PA academics and practitioners. Admittedly, the recommendations are not "miracle workers" or "magic formulas" but if adopted, they have the tendency to: (1) bridge the theory-practice and research-practice gaps; (2) stop or prevent the "family feud" between PA academics and practitioners and remove the divide between them; and (3) move the PA profession in the right direction as originally intended by its founding fathers.

But there is one caveat. It is written, before kingdoms change, men and, presumably women, must change. Put another way around, it is also written: "strip off the old nature and put on the new man/woman". What all this means is that the recommendations are not self-executing. Rather, they will be executed by both the PA academics and practitioners. Until these folks change their thinking, perceptions, mentalities, cannibalistic attitude toward each other and way of doing the public administration business - a mental revolution in public administration - the recommendations will only be as good as they sound. That said, here are the author's recommendations to bridge the theory-practice and the research-practice gaps, remove the divide or disconnect between PA academics and practitioners, and move the PA profession in the right direction.

\section{Recommendations}

First and foremost, in every PA article, there should be a statement of oath on the first page before the "abstract" that says something like this: This theory and/or research is, to the best of my knowledge, true, relevant, meaningful, useful, problem-driven and is intended to address, in whole or in part, the critical and daunting problems facing PA practitioners; so help me God. 
The second recommendation is summarized in five words: Faculty members are not stupid. Here is the point. As long as academic institutions have a culture of publish or perish, a faulty faculty reward system, and a self-serving attitude to focus on their own interest, not the interest of the PA practitioners, the theory-practice and research-practice gaps and the disconnect problem between PA academics and practitioners will continue to get worse because what is rewarded is always repeated. Therefore, it is hereby recommended that in order to avoid this "academic moral hazard" problem in academia, especially public administration, academic institutions should relax their "one-sided" publish or perish policy and take the "middle-of-the-road" approach—a research approach that takes into account the interests of both the PA academics and practitioners. This will enable faculty members to wear two hats at the same time-doing research that serves the needs of their academic institutions and the needs of the PA practitioners. After all, the goal should be "unity” between the two parties, not "division" to avoid creating yet another false dichotomy in public administration.

Third, as a conflict resolution strategy, PA practitioners should try to understand the politics of academic research and publication and work with the PA academics as much as they can. As has been stated, the name of the game in academia is publish or perish which simply means "publish or get out of here". Given this matching order, faculty members have no choice than to respond accordingly because they are not stupid. That is, in order for them to survive in such a "survival of the fittest" environment, they have to, at any cost, publish whatever pleases their employers (academic institutions). Given these facts, PA practitioners should understand that the problem is the academic institutions' crazy publish or perish policy, not the innocent faculty members who are only trying to keep their jobs.

The author's fourth and final recommendation is a good pill but it is hard to swallow. Nevertheless, here it is. If PA academics and practitioners cannot resolve or bridge the theory-practice and research-practice gaps between them, it is hereby recommended that we go back to the old "pracademic" days when public administration as a field of study was highly respected and reputed in the United States. As stated earlier, Henry (1995) justified the idea of pracademics in public administration when he said: Public administration reached its reputational zenith during the period from 1927 to 1937; public administrationists were courted by industry and government alike during the 1930s and early 1940s for their managerial knowledge (and expertise). In support of Henry's justification for the idea of pracademics, here is the rationale for the recommendation.

PA academics should not only craft theories and conduct research; they must also learn the business of public administration in a practical way. To demonstrate, in the medical field, there is no professor of surgery who has never seen a patient and perhaps operated on him/her, and yet today's public administration programs are overwhelmingly packed with fresh graduates right from the classroom with little or no practical experience. Even worse, some public administration faculty members, including tenured full professors, do not even know where their city hall is located nor have they seen their city's mayor and/or their county's sheriff let alone knowing the problems facing them. Ultimately, the losers in all of this are the students who are not properly equipped with the practical knowledge they need to hit the ground running when they graduate and to become efficient and effective public servants and managers.

In closing, the author feels that the time is ripe for the American public administration to regain its intellectual and professional image, prestige, and reputation as it did in the late 1920s through the early 1940s. Surely, this can be done by renewing the marriage vow between the PA academics and practitioners - a healthy and professional working relationship and partnership between the two-to achieve the objectives of government programs and policies, which as stated earlier, is their fundamental call of duty and responsibility. 
With the growing demand for government at all levels to do more with less and at the same time meet citizens' increased demand for more and better services, a collaborative working relationship and partnership between the PA academics and practitioners is an effective way to meet those challenges, not theories and research that are not tailored to meet the needs of the PA practitioners.

\section{References}

Behn, R. D. (1993). Case-Analysis research and managerial effectiveness: Learning how to lead organizations up sand dunes. In B. Bozeman (Ed.), Public management: The state of the art (pp. 40-54). San Francisco, CA: Jossey-Bass Publishers, Inc.

Behn, R. D. (1995). The big questions of public management. Public Administration Review, 55(4), 313-324.

Bennis, W., \& O’Toole, J. (2005). How business schools lost their way. Harvard Business Review, 83(5), 96-104.

Beyer, J. M., \& Trice, H. M. (1982). The utilization process: A conceptual framework and synthesis of empirical findings. Administrative Science Quarterly, 27(4), 591-622.

Bolton, M. J., \& Stolcis, G. B. (2003). Ties that do not bind: Musings on the specious relevance of academic research. Public Administration Review, 63(5), 626-630.

Burns, T., \& Stalker, G. M. (1994). The management of innovation. New York, NY: Oxford University Press.

Bushouse, B. K., Jacobson, W. S., Lambright, K. T., LIorens, J. J., Mores, R. S., \& Poocharoen, O.-O. (2011). Crossing the divide: Building bridges between public administration practitioners and scholars. Journal of Public Administration Research and Theory, 21(1), i99-i112.

Cook, B. J. (1995). At the crossroads of the real and the ideal: Woodrow Wilson's theory of administration. Administrative Theory \& Praxis, 17(2), 15-28.

Edelman, P. (2012). Poverty in America: Why can't we end it? Retrieved from http://www.foreconomicjustice.org/.../poverty -in-america-why-cant-we-end-it

Englehart, J. K. (2001). The marriage between theory and practice. Public Administration Review, 61(3), 371-374.

Gibson, P. A., \& Deadrick, D. (2010). Public administration research and practice: Are academician and practitioner interests different? Public Administration Quarterly, 34(2), 145-168.

Goodnow, F. J. (1900). Politics and administration. New York: Macmillan.

Gore, A. (1993). From red tape to results: Creating a government that works better and costs less. The Report of the National Performance Review. Washington, D.C.: US Government Printing Office.

Hartmann, J., \& Raadschelders, J. (2011). Practitioners and academicians: About gap, authority and bridges. PA Times, (August/September), 25.

Henry, N. (1995). Public administration and public affairs. Englewood Cliffs, NJ: Prentice Hall.

Johnson, L. B. (1964a). Annual message to the congress on the state of the union. Retrieved from http://www.presidency.ucsb. edu/ws/?pid

Johnson, L. B. (1964b). Modern history sourcebook: President Lyndon B. Johnson: The war on poverty. Retrieved from http:// legacy.fordham.edu/hals11/mod/1964johnson-warpoverty.html

Kettl, D. F. (2000). Public administration at the millennium: The state of the field. Journal of Public Administration Research and Theory, 10(1), 7-34.

Khurana, R., \& Marquis, C. (2006). Diagnosing and dissolving our “translation gap”. Journal of Management Inquiry, 15(4), $406-409$.

Lawler III, E. E., Mohrman Jr., A. M., Mohrman, S. A., Ledford Jr., G. E., \& Cummings, T. G. (1999). Doing research that is useful for theory and practice. Lanham, MD: Lexington Books.

MacArthur, B. (Ed.). (1996). The penguin book of historic speeches. New York, NY: Penguin Books.

Markides, C. (2007). In search of ambidextrous professors. Academy of Management Journal, 50, 762-768.

McGregor, D. (1960). The theory of human enterprise. New York, NY: McGraw-Hill.

Meyer, J. (2001). A leader in the making: Essentials to being a leader after God's own heart. New York, NY: Faith Words.

Milakovich, M. E., \& Gordon, G. J. (2004). Public administration in America. Belmont, CA: Wadsworth/Thomson Learning.

Mintzberg, H. (1973). The nature of managerial work. New York, NY: HarperCollins Publishers.

Mintzberg, H. (2004). Managers not MBAs. San Francisco, CA: Berrett-Koehler Publishers, Inc.

Mitchell, F. H., \& Mitchell, C. C. (2015). Thoughts about theory and practice in public administration. PA Times, 1(2), 12.

Moe, R. C. (1994). The "reinventing government” exercise: Misinterpreting the problem, misjudging the consequences. Public Administration Review, 54(2), 111-122. 
Newland, C. A. (2000). The public administration review and ongoing struggles for connectedness. Public Administration Review, 60(1), 20-38.

Odezah, S. I. (2016). The paradox of the American war on poverty. Journal of US-China Public Administration, 13(1), 41-54.

Perry, J. L. (1993). Public management theory: What is it? What should it be? In B. Bozeman (Ed.), Public management: The state of the art (pp. 16-18). San Francisco, CA: Jossey-Bass Publishers, Inc.

Pierce, G. F. A. (2001). Spirituality@work: 10 ways to balance your life on-the-job. Chicago, IL: Loyola Press.

Pollitt, C. (2010). Envisioning public administration as a scholarly field in 2020. Public Administration Review, 70(s1), S292-S294.

Posner, P. L. (2009). The pracademic: An agenda for re-engaging practitioners and academics. Public Budgeting \& Finance, 29(1), 12-26.

Rector, R. (2014). The war on poverty: 50 years of failure. Retrieved from http://www.washingtontimes.com/...rector -the-war-on...

Rosenbloom, D. (1983). Public administration theory and the separation of powers. Public Administration Review, 43(3), 219-227.

Schick, A. (1975). The trauma of politics: Public administration in the sixties. In F. C. Mosher (Ed.), American public administration: Past, present, future. Alabama: The University of Alabama Press.

Shields, P. (2006). Using pragmatism to bridge the gap between academe and practice. Retrieved from https://digital.library. txstate.edu/bitstream/handle/10877/3955/fulltext.pdf?sequence...

Stallings, R. A. (1986). Doctoral programs in public administration: An outsider's perspective. Public Administration Review, 46(3), 235-240.

Stillman, R. J. (1987). The constitutional bicentennial and the centennial of the American administrative state. Public Administration Review, 47(1), 4-8.

Stivers, C. (2000). “An impossible job”: Report on the building bridges tour. Public Administration Review, 60(3), 194-199.

Streib, G., Slotkin, B. J., \& Rivera, M. (2001). Public administration research from a practitioner perspective. Public Administration Review, 61(5), 515-525.

Susman, G., \& Evered, R. D. (1978). An assessment of the scientific merits of action research. Administrative Science Quarterly, 23(4), 582-603.

Tanner, M. (2012). The American welfare state: How we spend nearly \$1 trillion a year fighting poverty-And fail. Retrieved from object.cato.org/pubs/pas/PA694.pdf

Thomas, G. (1994). Introduction-A view from the trench. In G. Thomas (Ed.), Travels in the trench between child welfare theory and practice: A case study of the failed promises and prospects for renewal (pp. 1-31). Binghamton, NY: Haworth Press, Inc.

Tsui, A. S. (2013). The spirit of science and socially responsible scholarship. Management and Organization Review, 9(3), 375-394.

Ventriss, C. (1991). Contemporary issues in American public administration education: The search for an educational focus. Public Administration Review, 51(1), 5-14.

Waldo, D. (1968). Scope of the theory of public administration. In J. C. Charlesworth (Ed.), Theory and practice of public administration: Scope, objectives, and methods (pp. 1-26). Philadelphia, PA: American Academy of Political and Social Science.

Watson, D. J., \& Montjoy, R. S. (1991). Research on local government in public administration review. Public Administration Review, 51(2), 166-170.

Wilkerson, J. M. (1999). On research relevance, professors' “real world” experience, and management development: Are we closing the gap? Journal of Management Development, 18(7), 598-613.

Wills, G. (Ed.). (1982). The federalist papers by Alexander Hamilton, James Madison and John Jay. New York, NY: Bantam Books.

Wilson, W. (1887). The study of administration. Political Science Quarterly, 2(2), 197-222.

Wilson, W. (1941). The study of administration. Political Science Quarterly, 56(4), 481-506. 